\title{
Competition in Malaysian Audit Industry: What the Market is Telling Us?
}

\author{
Shamharir Abidin \\ School of Accountancy, Universiti Utara Malaysia, Kedah, Malaysia \\ Email: sham1202@uum.edu.my \\ Mohamad Naimi Mohamad-Nor
}

School of Accountancy, Universiti Utara Malaysia, Kedah, Malaysia

Email: naimi@uum.edu.my

\section{Doi:10.5901/mjss.2016.v7n1p306}

\begin{abstract}
The dominance of only a few audit firms in the market is of concern due to the possibility of market abuse and subsequently poor quality of audit work. While many studies of market structure have focused mainly on developed and efficient capital markets, fewer have studied the issue in emerging markets such as Malaysia. This paper highlights the structure of Malaysian audit market and assesses the level of market competition. The results suggest that the Malaysian audit market is of oligopoly type, with the top 10 audit firms dominating more than 91 percent of the market. Interestingly, there is also evidence that one of the Big Four is losing its grip in the market and one of the non-Big Four players is eyeing a position in the top four. This indicates the possibility that the barrier to entry has begun to collapse, as smaller audit firms enjoy better opportunities to enter the market.
\end{abstract}

Keywords: Audit Industry, Market competition, Market Share, Oligopoly, Malaysia.

\section{Introduction}

The study of audit market concentration has attracted the interest of regulators, market participants, and academics for many years (Abidin et al., 2010). The interest is partly due to concerns about the anticompetitive implications due to the rising levels of concentration after the merger between Ernst \& Whinney and Arthur Young, and between Deloitte, Haskins \& Sells and Touche Ross in 1989. The two mergers have created Ernst \& Young and Deloitte \& Touche, respectively. The merger also reduced the major accounting network from eight (which was known as the Big Eight) to six (Big Six). The original eight largest audit firms were Arthur Andersen, Arthur Young \& Co., Coopers \& Lybrand, Ernst \& Whinney, Deloitte Haskins \& Sells, Peat Marwick Mitchell, Price Waterhouse and Touche Ross. Almost ten years later, there was another mega merger between two top eight firms (i.e. the merger between Price Waterhouse and Coopers \& Lybrand) in July 1998 to form PricewaterhouseCoopers. Hence, the Big Six became the Big Five. Interest and concern about the audit market escalated in 2002, when one the Big Five (i.e. Andersen) was found guilty by the US Court for obstruction of justice for shredding important documents related to the audit of Enron Corporation. The result from the conviction caused Andersen to cease operation worldwide. Following Andersen's demise in 2002, the audit market now is left with fewer choices of auditors. Today, there are technically only four main audit firms that collectively are known as the 'Big Four' to offer audit services to major companies. The reduction has tremendously increased the audit market concentration and has brought in the issue of anticompetitive behavior among auditors in the audit market worldwide, including in Malaysia.

Even though there are many studies examining audit quality in Malaysia, only a few had examined from industrial organizational point of view. The study on audit market structure is not getting much recognition in Malaysia, possibly due to lack of awareness on how the structure could affect the firms' performance. The main concern of increased concentration is mainly on the possibility that the major service providers (i.e. the Big Four firms) would have tacit or explicit cartel-like agreements among them. Reduced competition due to excessive concentration would either harm consumers by leading to an increase in the price of the services provided by the auditor. Lack of competition might also hamper audit effort and consequently, might jeopardize audit quality. If that is the case, then the capital market will suffer in the long run caused by lack of confidence on the quality of financial reports. In order to assess market competition, it is therefore important to identify the structure of the market. Thus, the present study is set to provide an overview of audit 
market in Malaysia. In particular, the study is intended to investigate individual audit firm's market domination and to assess the market competition for listed companies' audits.

We have organized the paper as follows. The next section discusses the Industry Organizational Theory and presents prior studies of audit market in Malaysia. It is followed by the outline of the methods employed in section 3. Then, in section 4, a discussion on the results is presented. The final section concludes the study.

\section{Theory of Industrial Organization and Prior Studies}

Industrial organization is a study of the behavior of firms as sellers and buyers of output that builds on the theory of the firm. Such study is important in order to understand how industries work and more specifically, how the way they are organized affects how they work (Tirole, 1998). Yardley et al., (1992) and Beattie \& Fearnley (1994) provide an excellent review of industrial organization theory and its relation to the audit market. The studies highlight that increased concentration leads to increase in market power, while less concentration increase market competition and lower prices. This association is known as the Structure-Conduct-Performance (SCP) paradigm approach to industrial organization. The SCP approach holds that performance is determined by the conduct of firms, which in turn is determined by the structural characteristics of the market (Ferguson \& Ferguson, 1994).

Mansfield (1979) classifies the market into four basic structures that exist in the economy. The extreme forms are perfect competition and monopoly structure. The former can be categorized as purely competitive market in which companies have no control over prices while the latter is dominated by only one company and it has control over the price. However, these two forms of market structure are very rare, the most common are those between the two monopolistic competition and oligopoly. Monopolistic competition is a type of imperfect competition in which many producers sell products that are different from other sellers and there is no perfect substitute (Krugman et. al., 2008). On the other hand, an oligopoly is a market form in which a market (or industry) is dominated by only a small number of sellers. They (i.e. oligopolists) tend to impose barriers in order to prevent competitors from joining the market. One characteristics of the oligopoly market is the ability to form cartel and tacit collusion. Cartel is an agreement between competing firms to control prices or to exclude entry of new competitors, while tacit collusion (or price leadership) occurs where firms undergo actions that are likely to minimize a competitive response from other firms. For instance, when a dominant firm established a price change, other firms then will follow. According to Mansfield (1979), collusion in oligopolistic industries is promoted, since the number of firms is small and firms recognized their interdependence. Because of collusion, oligopolists will enjoy increased profits, decreased uncertainty, as well as a better opportunity to control the entry of new firms.

Prior studies of audit market concentration suggest that the increase in market concentration could occur for three reasons- (i) voluntary realignment, (ii) changes in the set of service buyers; and (iii) changes in the set of suppliers. Voluntary realignments refer or happen when companies initiate the auditor change. In many countries, companies are free to change auditor with approval from shareholders. The known reasons for voluntary realignment include high audit fee, dissatisfaction, changes in top management, need for reputable auditors and company mergers or takeovers. Meanwhile, changes in the set of consumers result from new companies entering or exiting the market. In the case of the market for listed companies, delisting and temporary suspension could also affect the concentration level. Changes in the set of supplier can occur as a result of an audit firm merger or demise, though it is rare.

Evidences suggest that the audit industry is an oligopoly. In developed markets such as the US and UK, the audit industry is dominated by top four firms with over 60 percent of market share. Referring to the definition of oligopoly by the US Government Accountability Office (GOA), the market can be classified as 'tight oligopoly'. This signifies that the other players (i.e. non-top four) face significant barriers to entry into the market The barriers may take the form of reputation, size or capacity constraints, limited access to capital, litigation risk, lack of expertise, lack of global networks and alliances, regulations and independence requirements(GOA, 2003). Thus, smaller firms are not expected to reach the size of the top firms, at least in the short run (Ascher, 2008). From the audit market perspective, lack of auditor choice will lead to poor quality audit services and in the long run is very detrimental to the capital market.

However, evidence from audit market concentration studies also suggests that increased market concentration does not necessarily decrease competition. For instance, while the merger between Price Waterhouse and Copper \& Lybrand increased the Big Five (now Big Four) market share at the aggregate market level, Thavapalan et al. (2002) report that, for a number of industry sectors in Australia, a more equitable spread of audit clients between the Big Five firms was achieved. A study by the Government Accountability Office (GOA) in the US also found no empirical support to the contention that competition in the service market has been impaired (GOA, 2003).

To date, the study of audit market structure is considered scarce in Malaysia. Iskandar et al. (2000) undertook the 
first study of concentration in the Malaysian audit market. They, however, analyzed concentration on the basis of the audit fees audits of listed companies at firm's level and observed that the Big Six firms (now Big Four) audited 57.2\% and about $65.1 \%$ of the market in 1991 and 1996, respectively. The study also reports that the market was not equally distributed among the firms. Interestingly, when decomposing the analysis into three segments of audit fees size, they reveal that the non-Big Six surpassing the Big Six in term of audit fees in the small and large market segments. Only in the medium segments was the Big Six audit market share higher than that of smaller firms. The only other study of audit market concentration in Malaysia was undertaken by Ali et al. (2006). They examined the Big Five market share and found evidence that also indicates large firms' domination.

\section{Dataset Selection and Measurement of Audit Market Share}

The dataset used in the present study covers all companies listed on the Bursa Malaysia (Malaysia Bourse) for the year 2008 and 2009. In 2008, there were 957 companies listed on the exchange and then increased slightly to 968 in 2009. All information required (auditor name and audit fee) were hand-collected from the individual company's annual reports.

The market shares for each firm are calculated based on the number of audit and total audit fees. The k-firm concentration ratio measures the proportion of total output in the market produced by a given number of the largest firms in the industry. It is calculated as follows:

$$
C R_{k}=\frac{\sum_{1}^{k} x_{i}}{\sum_{i}^{n} x_{i}}
$$

where,

$\mathrm{CR}=$ Concentration Ratio

$\mathrm{k}=$ the number of largest firms considered.

$\mathrm{n}=$ the total number of audit firms in the market

$\mathrm{xi}=$ the size of the audit firm (measured as number of audits or audit fees).

The present study computes the concentration ratio of the top 4, 6, 8 and 10 firms (CR4, CR6, CR8 and CR10). For comparison purposes, we have also calculated the concentration ratio of the Big Four firms (CR-Big 4).

In general, economists classify the market structure according to the CR4. Where the CR4<40\% is regarded as effectively competitive, CR4 between $40 \%$ to $60 \%$ is defined as loose oligopoly, CR4 > 60\% as tight oligopoly, and CR1 > $90 \%$ as effectively monopoly.

\section{Results and Discussion}

Table 1 and Table 2 show a detailed analysis of market shares by individual firm, on the basis of both number of audits and audit fees for 2008 and 2009. Several observations can be made from this table. First, the results reveal that, as in the developed market, the audit services market for large clients is clearly dominated by the so-called Big Four audit firms. To be more accurate, the market is dominated by firms with international affiliations. In markets that offer intangible products such as the audit services market, reputation plays a major role to signal quality and subsequently attract more clients. Given their long history in the business, these international firms rely on their reputation as world's major suppliers to build their clientele here in Malaysia.

It has also been claimed that these firms have access to more audit resources and technology in addition to wider global networking. Thus, this enables them to offer audit services at higher quality than what the locals can do. However, it is also evidenced that most audit failures and lawsuits against auditors have involved these top firms. One prominent example is the Andersen-Enron case in the US. Other examples include PWC-Satyam case in India and Crowe HorwathSilver Bird case in Malaysia. Andersen, PwC and Crowe Horwath are all renowned audit firms in the world. To date, there are more than 1300 audit firms in Malaysia. However, in 2008, only 87 audit firms that audited KLSE's companies. In 2009, the number increased to 90 audit firms. The statistics thus suggest that fewer than $6.9 \%$ of active firms have access to the audit market of listed companies.

Second, the table also reveals that, on the basis of audit fees earned, E\&Y, PWC and KPMG spot the top three positions in the market. The three firms collectively audited more than $72 \%$ and \& $71 \%$ of public listed companies in 2008 and 2009, respectively. 
Table 1. Summary of firm' market share based on audit fees

\begin{tabular}{|c|c|c|c|c|}
\hline & \multicolumn{4}{|c|}{ Market Share Based on Audit Fees } \\
\hline & \multicolumn{2}{|c|}{2008} & \multicolumn{2}{c|}{2009} \\
\hline Auditors & Rank & $\%$ & Rank & $\%$ \\
\hline E\&Y & 1 & 30.77 & 1 & 30.27 \\
\hline PWC & 2 & 28.70 & 2 & 29.10 \\
\hline KPMG & 3 & 12.60 & 3 & 12.62 \\
\hline Deloitte & 4 & 5.54 & 5 & 4.53 \\
\hline Total Big Four & & 77.61 & & 76.52 \\
\hline BDO & 5 & 5.13 & 4 & 4.60 \\
\hline Horwath & 6 & 3.00 & 6 & 3.73 \\
\hline HLB & 7 & 1.79 & 7 & 1.93 \\
\hline MR & 8 & 1.70 & 8 & 1.60 \\
\hline BT & 9 & 1.33 & 9 & 1.47 \\
\hline GT & 10 & 1.30 & 10 & 1.41 \\
\hline Others & & 8.14 & & 8.74 \\
\hline $\boldsymbol{\Sigma}$ 'Non-Big Four' & & 22.39 & & 23.48 \\
\hline Grand $\Sigma$ & & 100.00 & & 100.00 \\
\hline
\end{tabular}

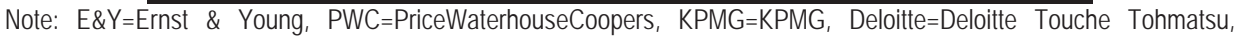
$\mathrm{BDO}=\mathrm{BDO}$ Binder, Horwath=Crowe Horwath, HLB=HLB Ler Lum, MR=Moore Rowland, BT=Baker Tilly, GT=Grant Thornton.

Among the Big Four firms, Deloitte is the only firm that audits less than $10 \%$ of the market. With around $5 \%$ market share, Deloitte has positioned itself as the smallest among the Big Four for 2008 and 2009 with only $5.54 \%$ and $4.53 \%$ market share in the year 2008 and 2009, respectively. The closest rival to Deloitte is BDO Binder with 5.54\% market share in the year 2008. In 2009, BDO Binder marginally overtook Deloitte with 4.6\% market share. Collectively, the non-Big Four firms audit around 23\% of the market. The top 6 non-Big Four firms, however, hold around 14\% market share, leaving the other non-Big 4 with only around $8 \%$ market share.

Third, per table 2 which measures market share using the number of audits as a basis, a slight different pattern can be observed. While E\&Y and KPMG retain their positions at the top three, PwC only managed reach the position in 2008. In 2009, Horwath replaced PwC. With backup from more than 52 partners, principals and directors, it has been reported elsewhere that the firm is also positioned it-self in the Initial Public Offer (IPO) market. Clearly, this strategy has successfully placed the firm as one of the strongest contenders for the Big Four firms. Collectively, non-Big Four audits more than $43 \%$ and $46 \%$ of the market in 2008 and 2009, respectively. The Big Four, on the other hand, still dominate the market with over $50 \%$ market share.

The statistics of both audit fees and number of clients suggest that while auditing fewer audit clients, the Big Four is now focusing on bigger clients that obviously will pay more in term of fees. This evidence together with the increase domination of non-Big Four in the IPO market could suggest that the Big Four is be-coming very selective when come to client acceptance decision. The firms tend to audit less risky clients and leave the riskier ones to the non-Big Four. This is perhaps a lesson learned by the Big Four following Andersen demise in 2002 - suggesting that the Big Four, despite controlling the market, may lose business as a result of clients' business failures. Avoiding risky clients also serves as a preventive measure from increasingly costly lawsuits against auditors

Table 2. Summary of firm' market share based on number of audits

\begin{tabular}{|c|c|c|c|c|}
\hline & \multicolumn{4}{|c|}{ Market Share Based on Number of Audits } \\
\hline & \multicolumn{2}{|c|}{$\mathbf{2 0 0 8}(\boldsymbol{n}=957)$} & \multicolumn{2}{c|}{$\mathbf{2 0 0 9}(\boldsymbol{n}=\mathbf{9 6 8})$} \\
\hline Auditors & Rank & $\%$ & Rank & $\%$ \\
\hline E\&Y & 1 & 26.85 & 1 & 25.52 \\
\hline KPMG & 2 & 14.73 & 2 & 14.05 \\
\hline PWC & 3 & 8.15 & 4 & 8.16 \\
\hline Deloitte & 5 & 6.90 & 5 & 5.68 \\
\hline $\mathbf{\Sigma}$ Big Four & & $\mathbf{5 6 . 6 3}$ & & $\mathbf{5 3 . 4 1}$ \\
\hline Horwath & 4 & 7.84 & 3 & 9.61 \\
\hline
\end{tabular}




\begin{tabular}{|c|c|c|c|c|}
\hline BDO & 6 & 5.12 & 7 & 4.96 \\
\hline GT & 7 & 4.39 & 6 & 5.06 \\
\hline BT & 8 & 2.30 & 8 & 2.89 \\
\hline MS & 8 & 2.30 & 10 & 1.76 \\
\hline MR & 10 & 1.57 & 11 & 1.55 \\
\hline UHY & 10 & 1.57 & 9 & 1.86 \\
\hline Others & & 7.21 & 12 & 0.83 \\
\hline $\boldsymbol{\Sigma}$ 'Non-Big Four' & & 43.37 & & 46.59 \\
\hline Grand $\Sigma$ & & 100.00 & & 100 \\
\hline
\end{tabular}

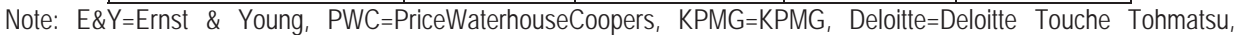
Horwath=Crowe Horwath, BDO=BDO Binder, GT=Grant Thornton, BT=Baker Tilly, MS=Moore Stephens, MR=Moore Rowland, UHY=Urbach Hacker Young.

Table 3 reports the level of audit market concentration in 2008 and 2009. Generally, the k-firm con-centration reflects a decrease in concentration in 2009 as compared 2008. The only exception is for the CR10 based on number of clients, indicating that the top ten firms have managed to increase their clients, albeit marginally. Focusing on the concentration statistics measured by audit fees, the level of audit market concentration in Malaysia during the period was considered high, but not as high as in developed markets.

In 2008, the top four and B4 firms audited around $77 \%$ and $77.3 \%$ of the market, respectively. In term of number of audits, the reported Concentration Ratios are lower than those using the fees as basis. This indicates that the audit market distribution based on number of clients for the two years were relatively competitive. However, CR measures based on audit fees suggest that only a few firms audited most of the clients. Looking at CR10 statistics, more than 90\% of the audit market fees went to the top 10 ten audit firms, leaving less than $10 \%$ to be shared by the other 80 firms (or 77 firms in 2008). Consistent with work by Beattie et al. (2003), the Malaysia audit market may be categorized either as tight or loose oligopoly-depending on the base measures used. As such, it is not unexpected that smaller firms are faced with significant barriers to entry which prevent them from entering the market (Abidin et. al. 2010).

However, Beattie et al. (2003) also emphasized that the presence of high market share is no longer believed by industrial economists necessarily to lead to anti-competitive behavior. High market share can be translated into bigger clientele based, enabling the firms to achieve economies of scale. In return, the firms could offer the same product at a lower price per unit.

Table 3. Audit market concentration (2008-2009)

\begin{tabular}{|c|c|c|c|}
\hline & & \multicolumn{2}{|c|}{ Measures } \\
\hline Concentration Ratios & Years & Number of clients & Audit fee \\
\hline \multirow{2}{*}{ CR4 } & 2008 & $57.58 \%$ & $77.61 \%$ \\
\cline { 2 - 4 } & 2009 & $53.41 \%$ & $76.59 \%$ \\
\hline \multirow{2}{*}{ CR6 } & 2008 & $69.59 \%$ & $85.74 \%$ \\
\cline { 2 - 4 } & 2009 & $68.08 \%$ & $84.85 \%$ \\
\hline \multirow{2}{*}{ CR8 } & 2008 & $76.28 \%$ & $89.23 \%$ \\
\cline { 2 - 4 } & 2009 & $75.93 \%$ & $88.38 \%$ \\
\hline \multirow{2}{*}{ CR10 } & 2008 & $79.41 \%$ & $91.86 \%$ \\
\cline { 2 - 4 } & 2009 & $79.55 \%$ & $91.26 \%$ \\
\hline \multirow{2}{*}{ CR Big Four } & 2008 & $56.63 \%$ & $77.61 \%$ \\
\cline { 2 - 4 } & 2009 & $53.41 \%$ & $76.52 \%$ \\
\hline
\end{tabular}

\section{Summary and Conclusion}

The present study provides an overview of audit market in Malaysia by investigating individual audit firm's market domination and assessing the market competition for listed companies' audits. The analysis was based on the information collected from 957 and 968 companies' annual report for the year 2008 and 2009, respectively.

The present study contributes to both the industrial organization and audit literature. The results of the study suggest that the audit market in Malaysia exhibits behavior best described as 'oligopoly' structure. We provide evidence that the top four audit firms, i.e. Ernst \& Young, PriceWaterhouseCoopers, KPMG and Deloitte Touche Tohmatsu are remained as the main player in the audit market. With the dominance of only a few firms, the issue of anticompetitive 
behavior is worth highlighting. The other issue to consider is whether the big firms are imposing barriers to entry to the market, which then resulted in small firms' difficulty to gain bigger market share. Given significant increase of Big 4's CR since 1991 (i.e. $57.2 \%$ to $76.6 \%$ ), it is timely for the authority to review the state of competition in the audit market before it affects the quality of audit service and the capital market. However, evidences also suggest that this domination might not last long as smaller firms, such as BDO and Horwath, are now gaining more clients. Arguably, the trend indicates that, at least in Malaysia, companies have begun to accept non-Big 4 as quality service providers. Policy makers should now find ways on how to encourage more public companies to choose non-Big 4 as their auditors and also to break the entry barriers. Theoretically, this move will enhance the service quality and auditor independence.

This study is not without limitations. First, the time period included in this study only covers the year 2008 and 2009. Arguably, in order to provide deeper understanding of the market structure, a longer period is necessary. Additionally, by including the most recent dataset, a much more meaningful observation can be made. Second, the implicit assumption of the current analysis is that the audit firms only provide the services to listed companies, when, in reality, their clientele also include non-listed companies. As such, the results of this study might only capture 'part' of the audit market. It is important to remind that, the results and implications of this study should be considered with these limitations in mind.

Research on audit market concentration may be extended in several ways. First, future research should consider including a longer time period in order to assess the competition in the audit market. Second, the sample should include audit clients from non-listed segment in order to assess whether barriers to entry also exist in that segment.

\section{Acknowledgements}

We are grateful to Universiti Utara Malaysia (UUM) for the funding support of this research through the PIBT Research Grant.

\section{References}

Abidin, S., Beattie, V. and Goodacre, A. (2010). Audit market structure, fees and choice in a period of structural change: Evidence from the UK-1998-2003. British Accounting Review 42(3), 187-206.

Ali, A. Sahdan, H., Harun-Rasit, H. \& Lee, T.H. 2008. Audit specialization in Malaysia, International Journal of Business and Management 3(3), 91-99.

Ascher, B. 2008. The audit industry: World's weakest oligopoly? AAI Working Paper No. 08-03. The American Antitrust Institute.

Beattie, V., Goodacre, A. and Fearnley, S. 2003. And then there were four: A study of UK audit market concentration-causes, consequences and the scope for market adjustment. Journal of Financial Regulation and Compliance. 11(3), 250-265.

Beattie, V. and Fearnley. S. 1994. The changing structure of the Market for Audit services in The UK-A Descriptive Study. British Accounting Review. 26(4), 301-322.

Ferguson, P. R.; Ferguson, G. J. 1994. Industrial economics: issues and perspectives. London: MacMillan.

GAO. (2003). Public accounting firms: mandated study on consolidation and competition. General Accounting Office. [Online] Available: http://www.gao.gov (July 13, 2003).

Iskandar, T., Maelah, R. \& Aman, A. 2000. Audit market concentration and auditor's industry specialization: An empirical evidence in Malaysia. Utara Management Review. 1 (1), 93-112.

Krugman, P., Obstfeld, M. \& Melitz, M. (8th) 2008. International Economist: Theory and Policy. Addison Wesley.

Mansfield, E. 1979. Micro-Economics Theory and Applications (3rd ed.). New York and London: W.W. Norton and Company.

Thavapalan, S., Moroney, R. and Simnett, R. 2002. The effect of the PricewaterhouseCoopers merger on auditor concentration in Australia: A note. Accounting and Finance. 42(2), 153-157.

Tirole, J. 1988. The Theory of Industrial Organization. MIT Press.

Yardley, J. A., Kauffman, N. L., Cairney, T. D., \& Albrecht,W. D. 1992. Supplier behaviour in the US audit market. Journal of Accounting Literature. 11(1), 151-184. 